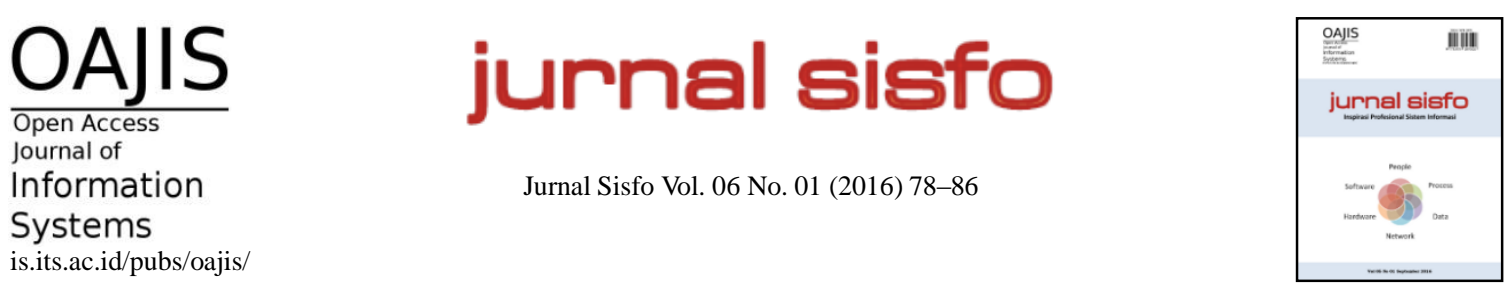

\title{
Pengembangan Fungsi Pengajuan Cuti Karyawan pada Sistem Absensi Mobile
}

\author{
Fransiskus Adikara* \\ Jurusan Teknik Informatika, Fakultas Ilmu Komputer, Universitas Esa Unggul
}

\begin{abstract}
Companies today need information systems that can manage human resources that have several places to attend the work. In previous research has developed attendance system based on GPS and MAC Address and now the function that required as addition in previous attendance system is self-service employee leave filling system. The goal of this researrch is the employees can apply or fill a leave form through mobile devices that use Android 5.x operating system and combined it with a GPS-based time attendance system. Extreme Programming method has conducted to develop this employee leave system. The research results show and demonstrate that the smart phone based on the Android operating system can be used to apply employee's leave in anywhere.
\end{abstract}

Keywords: Mobile Attendance Information System, Employee Leave, Mobile Software Engineering

\begin{abstract}
Abstrak
Perusahaan saat ini membutuhkan sistem informasi yang dapat mengelola informasi sumber daya manusia yang berkerja. Salah satu fungsi yang dibutuhkan dalam pengelolaan sumber daya manusia yaitu mengenai pengelolaan cuti karyawan. Untuk memenuhi kebetuhan tersebut, maka dikembangkan fungsi pengajuan cuti karyawan melalui aplikasi absensi di sistem absensi melanjutkan penelitian sebelumnya mengenai perancangan sistem absensi berbasis GPS dan pemanfaaatan MacAdrress. Tujuan yang ingin dicapai adalah karyawan dapat mengajukan cuti secara mandiri melalui perangkat mobile-nya yang menggunakan minimal sistem operasi Android 4.x untuk dikombinasikan dengan sistem Absensi berbasis GPS. Penelitian dilakukan dengan menggunakan metode pengembangan sistem dengan Extreme Programming. Hasil dari sistem absensi yang dikembangkan menunjukkan bahwa telepon pintar berbasis sistem operasi Android dapat digunakan untuk mengajukan cuti karyawan secara mandiri. Keberlanjutan dari sistem ini adalah pengembangan pula fasilitas login sistem yang lebih kredibel contohnya dengan menambahkan fasilitas pemindai data biometrik dari penggunanya.
\end{abstract}

Kata kunci: Sistem Absensi Mobile, Cuti Karyawan, Rekayasa Perangkat Lunak Mobile

(C) 2016 Jurnal SISFO.

Histori Artikel : Disubmit 24 Agustus 2016; Diterima 12 September 2016; Tersedia online 13 September 2016

${ }^{*}$ Corresponding Author

Email address: fransiskus.adikara@esaunggul.ac.id (Fransiskus Adikara) 


\section{Pendahuluan}

Pemanfaatan teknologi informasi dan komunikasi (TIK) di saat ini menjadi salah satu hal penting untuk meningkatkan nilai kompetitif perusahaan. Penggunaan sistem pada perangkat pintar bergerak (smartphone) merupakan salah satu jenis pemanfaatan TIK. Perusahan dapat menggunakan sistem tersebut dalam beberapa bagian yang diperlukan dalam mengoptimalkan kegiatan operasional. Pengembangan sistem absensi berbasis GPS yang dikembangka sebelumnya akan ditambahkan fungsi pengajuan cuti pada penelitian ini. Pada bagian ini akan menjelaskan latar belakang dari sistem ini dibuat dan juga tinjauan pustaka yang kami gunakan dalam penelitian.

Sistem informasi yang pasti digunakan dalam perusahaan adalah sistem untuk mengelola sumber daya manusia yang bekerja. Informasi mengenai sumber daya manusia sangatlah dibutuhkan oleh perusahaan guna menunjang kinerja sumber daya manusia tersebut dan juga menunjang kinerja perusahaan tersebut. Melanjutkan sistem absensi berbasis GPS (Global Posisition Sistem) [1] dan MAC Address [2].

Melanjutkan penelitian sebelumnya mengenai perancangan sistem absensi berbasis GPS [1], dan juga pengembangan sistem tersebut dengan pemanfaat teknologi lainnya sebagai penanda letak dari karyawan tersebut di dalam gedung bertingkat, yaitu menggunakan fasilitas WIFI Router (Hotspot) untuk kemudian mengirimkan MAC Address dari WIFI Router (Hotspot) [2], maka untuk membantu divisi personalia dalam tugas dan fungsi untuk melakukan pengolahan manajemen karyawan untuk mengelola masalah hak cuti.

Cuti sendiri terdiri dari cuti melahirkan, cuti sakit, cuti besar, cuti tahunan dan cuti karena alasan penting, menurut Undang-Undang No.13 tahun 2003 Pasal 79 ayat (2). Seorang pekerja berhak atas cuti tahunan sekurang kurangnya 12 hari kerja. Pada organsasi yang menggunakan sistem absensi, otomatis harus memiliki fitur dan fungsi pengelolaan cuti ini untuk melengkapi sistem absensi yang sudah ada, sehingga karyawan cukup menggunakan satu aplikasi dalam mengelola presensi kedatangannya di kantor.

Melihat dari permasalahan tersebut diperlukan suatu aplikasi pengajuan cuti yang tersistem, dapat diakses dimana saja baik melalui komputer ataupun melalui smartphone. Menurut penelitian sebelumnya, sudah ada perusahaan yang menerapkan aplikasi mandiri bagi pegawai atau disebut Employee Self-Service yang diperkenalkan untuk meningkatkan efisiensi dari sejumlah proses HRM dengan memungkinkan karyawan untuk mendaftar, permintaan dan memantau hubungan kontrak kerja dan manfaat, seperti liburan dan cuti [3]. Berdasarkan kebutuhan di atas, maka diperlukan penelitian dengan judul "Pengembangan Fungsi Pengajuan Cuti Karyawan pada Sistem Absensi Mobile".

\section{Tinjauan Pustaka/Penelitian Sebelumnya}

\subsection{Pengertian Sistem Absensi}

Sistem menurut [4] adalah suatu kesatuan usaha yang terdiri dari bagian-bagian yang berkaitan satu sama lain yang berusaha mencapai satu tujuan dalam suatu lingkungan kompleks. Menurut [5], absen adalah tidak masuknya seorang siswa/pegawai pada saat hari masuk/kerja karena sakit, izin, alpa, atau cuti. Sedangkan absensi adalah daftar kehadiran pegawai/siswa, yang berisi jam datang, jam pulang, serta alasan/keterangan kehadiran pegawai. Sedangkan Sistem Mobile [6][6][7] adalah sistem informasi yang dapat dijalankan dan bekerja di perangkat mobile. Jadi Sistem Absensi Mobil adalah sebuah kesatuan komponen-komponen untuk mengeola kehadiran pegawai yang berisi informasi mengenai keberaaannya pada perusahaan secara mobile. 


\subsection{Cuti Karyawan}

Menurut Undang Undang No. 13 Tahun 2003 Pasal 79 [8]:

1) Pengusaha wajib memberi waktu istirahat dan cuti kepada pekerja/buruh.

2) Waktu istirahat dan cuti sebagaimana dimaksud dalam ayat (1), meliputi:

a. Istirahat antara jam kerja, sekurang kurangnya setengah jam setelah bekerja selama 4 (empat) jam terus menerus dan waktu istirahat tersebut tidak termasuk jam kerja;

b. Istirahat mingguan 1 (satu) hari untuk 6 (enam) hari kerja dalam 1 (satu) minggu atau 2 (dua) hari untuk 5 (lima) hari kerja dalam 1 (satu) minggu;

c. Cuti tahunan, sekurang kurangnya 12 (dua belas) hari kerja setelah pekerja/buruh yang bersangkutan bekerja selama 12 (dua belas) bulan secara terus menerus; dan

d. Istirahat panjang sekurang-kurangnya 2 (dua) bulan dan dilaksanakan pada tahun ketujuh dan kedelapan masing-masing 1 (satu) bulan bagi pekerja/buruh yang telah bekerja selama 6 (enam) tahun secara terus-menerus pada perusahaan yang sama dengan ketentuan pekerja/buruh tersebut tidak berhak lagi atas istirahat tahunannya dalam 2 (dua) tahun berjalan dan selanjutnya berlaku untuk setiap kelipatan masa kerja 6 (enam) tahun.

3) Pelaksanaan waktu istirahat tahunan sebagaimana dimaksud dalam ayat (2) huruf c diatur dalam perjanjian kerja, peraturan perusahaan, atau perjanjian kerja bersama.

4) Hak istirahat panjang sebagaimana dimaksud dalam ayat (2) huruf d hanya berlaku bagi pekerja/buruh yang bekerja pada perusahaan tertentu.

5) Perusahaan tertentu sebagaimana dimaksud dalam ayat (4) diatur dengan Keputusan Menteri.

\subsection{Extreme Programming $(X P)$}

Extreme Programming [9][8] merupakan suatu model yang tergolong dalam pendekatan agile yang diusulkan oleh Kent Back. Menurut Presman, definisi XP adalah sebagai berikut: "Extreme Programming $(X P)$ is a lightweight, efficient, low-risk, flexible, predictable, scientific, and fun way to develop software“. Model ini cenderung menggunakan pendekatan Object-Oriented.

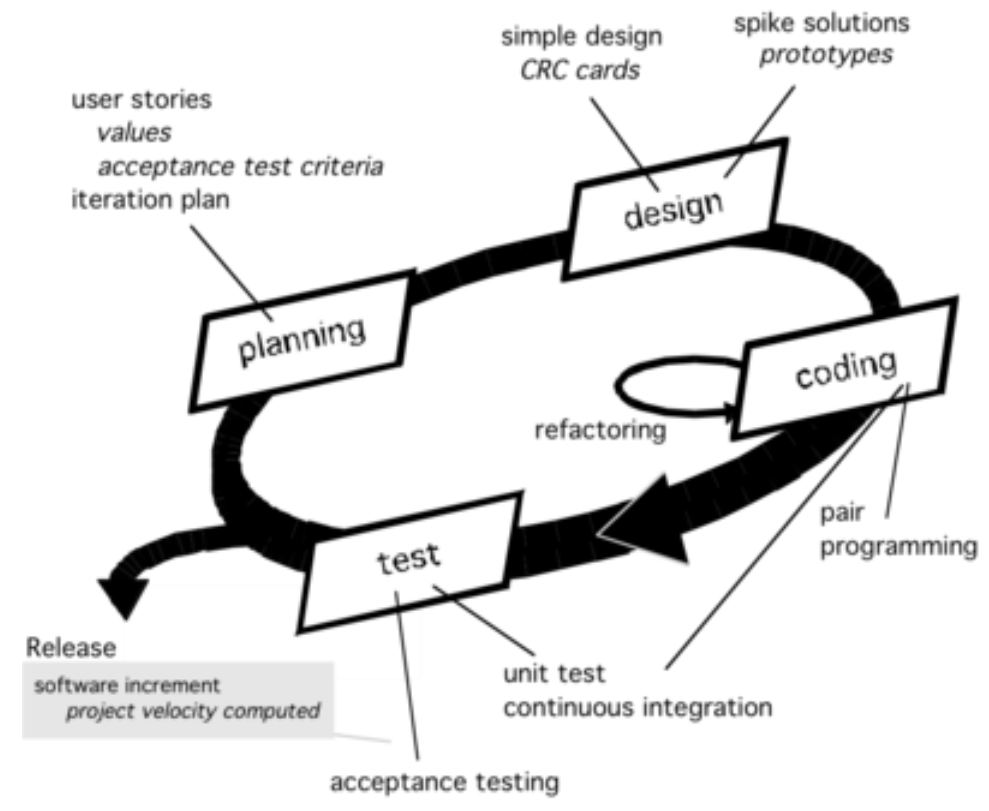

Gambar 1. XP Life Cycle [9] 
Aktifitas pada XP menurut [9] seperti pada Gambar 1 adalah sebagai berikut:

1) Aktifitas Perencanaan (Planning)

Pengumpulan user stories dari klien yang klien tetapkan prioritasnya. Setiap story ditetapkan harga dan lama pembangunan. Jika terlalu besar, story dapat dipecah menjadi beberapa story yang lebih kecil. Pada tahap ini juga perlu penentuan nilai dari sistem yang akan dibuat, kriteria penerimaan dari sistem ini, dan rencana iterasi.

2) Aktifitas Desain (Design)

Memanfaatkan kartu CRC (Class-Responsibility-Collaborator) untuk identi-fikasi dan mengatur class di konsep OO. Jika menemui kesulitan, prototype bisa dibangun dan disebut sebagai fase spike solution. Tahap ini juga bisa melakukan refactoring, yaitu mengembangkan desain dari program setelah ditulis

3) Aktifitas Pengkodean (Coding)

Menyiapkan unit test sebelum pengkodean dipakai sebagai fokus pemrogram untuk membuat program. Pair programming bisa dilakukan untuk real time program solving dan real time quality assurance.

4) Aktifitas Pengujian (Testing)

Menggunakan unit test yang dipersiapkan setelah pengkodean.

\section{Metodologi Penelitian}

Penelitian dilakukan dengan menggunakan metode SWOT untuk analisa masalah dan pengembangan sistem dengan metode Extreme Programming. Penelitian ini akan menganalisis masalah, melakukan perencanaan untuk kemudian di-coding sistemnya. Setelah selesai akan dilakukan pengecekan apakah hasilnya sesuai untuk digunakan sebagai sistem absensi berbasis GPS dan bisa mengajukan cuti karyawan.

Untuk pengembangan ini peneliti akan melakukan studi literature untuk mendapatkan proses pengajuan cuti, dan survey pada beberapa organisasi yang telah melaksanakan absensi jarak jauh dengan karyawannya yang bersifat bergerak untuk mendapatkan kebutuhan-kebutuhan fungsi pengajuan cuti. Setelah itu peneliti akan melakukan rancangan (design) menggunakan CRC untuk sistem yang akan dikembangkan untuk kemudian dicoding menggunakan bahasa pemrograman JAVA untuk diujicobakan pada perangkat bersistem operasi Android.

\section{Analisis dan Pengembangan}

Analisis masalah dilakukan dengan menggunakan SWOT dan untuk perancangannya akan menggunakan user stories dan Class Responsibility Collaboration [10].

\subsection{Analisa Masalah}

Berdasarkan pengamatan pada proses bisnis sebelumnya dan juga berdasarkan penggunaan sistem absensi pada penelitian sebelumnya [1][2], maka didapatkan hasil analisis dan pengamatan tersebut menggunakan analisis SWOT terhadap sistem absensi yang berjalan adalah sebagai berikut:

\section{1) Strength / Kekuatan}

a. Banyak karyawan yang menggunakan sistem mobile berbasis Android pada perangkat bergeraknya.

b. Perusahaan mempunyai infrastruktur internet yang semakin cepat untuk transaksi data pada web application dan sistem mobile.

c. Perusahaan memiliki web application dan database server untuk menajalankan usahanya.

d. Semakin banyaknya aplikasi yang bisa digunakan dan sangat murah untuk dikembangkan pada sistem berbasi Android.

e. Absensi karyawan menggunakan sistem absensi mobile sudah bisa dijalankan dengan baik. 
2) Weakness / Kelemahan

a. Keamanan sistem berbasis Android masih memiliki celah keamanan.

b. Fungsi sistem absensi mobile masih kurang lengkap untuk mengelola kegiatan kehadiran karyawan terutama masalah cuti.

c. Kegiatan pengajuan cuti karyawan masih dilakukan secara manual sehingga kegiatan menjadi tidak efisien, kurang menarik dan tidak berkembang.

d. Proses pengajuan cuti yang membutuhkan waktu yang lebih lama untuk pemeriksaan dokumen manual.

3) Opportunity / Kesempatan

a. Belum banyak tersedianya sistem absensi mobile dengan fungsi pengajuan cuti.

b. Tersedianya tools gratis yang digunakan dalam pembuatan aplikasi.

c. Tersedianya studi pustaka yang bisa digunakan untuk membantu pembuatan aplikasi ini.

d. Banyak perusahaan memerlukan sistem pengajuan cuti secara self-service secara mudah melalui perangkat yang dimiliki karyawan.

4) Threats / Ancaman

a. Berkembangnya sistem operasi Android yang diimbangi dengan berkembangnya virus yang merusak.

b. Keamanan data di sistem Android perlu ditingkatkan.

c. Data karyawan yang bisa saja diakses oleh pihak yang tidak berkepentingan.

d. Penggunaan sistem absensi oleh pihak yang tidak seharusnya.

Pemecahan masalah yang diajukan yaitu untuk menyelesaikan masalah berdasarkan analisis SWOT di atas yaitu dengan meningkatkan nilai dari Strength dan Opportunity. Selain dari analisis SWOT, melihat Gambar 2 mengenai activity diagram kegiatan pengajuan cuti secara manual, pemecahan masalahnya adalah dibuatnya suatu Aplikasi berbasis Android sehingga:

1) Fungsi pengajuan cuti karyawan dapat dilakukan pada sistem yang sama untuk melakukan absensi, sehingga tidak perlu ada sistem terpisah.

2) Kegiatan akan dilakukan dengan memanfaatkan teknologi informasi terutamanya menggunakan telepon pintar agar pengajuan cuti dan verifikasinya bisa secara otomatis dilakukan.

3) Kegiatan cuti karyawan menjadi lebih terkontrol dan tertata dengan baik karena terintegrasi dengan sistem absensi.

\subsection{Pengembangan Sistem}

Sistem dikembangkan menggunakan metode Extreme Programming (XP) mengingat waktu pengerjaan yang sangat singkat dan kebutuhan yang bersifat umum masih bisa berubah-ubah sesuai perusahaan yang menggunakannya.

\subsubsection{Aktifitas Perencanaan}

Pada tahap ini, penulis mengumpulkan user stories (kebutuhan pengguna). Kebutuhan pengguna ini diperoleh dari wawancara dengan narasumber yaitu karyawan pada perusahan yang bergerak di bidang IT Consultant. Karyawan pada perusahaan ini sering melakukan kunjungan ke pelanggannya di perusahaan lain, bahkan bekerja di kantor pelanggan tersebut untuk jangka waktu yang lama. Berdasarkan hasil wawancara dengan narasumber, maka kebutuhan usernya seperti yang dijabarkan pada Tabel 1.

Setelah mengetahui kebutuhan dari pengguna, maka pada tahap aktifitas perencanaan ini, yang dihasilkan adalah rencana untuk membangun aplikasi system absensi mobile. Kebutuhan lainnya yang bersifat nonfungsional adalah diperlukan telepon pintar yang memiliki fitur GPS [11], WiFi, dan terhubung dengan Internet, dari sisi keamanan perlu dibuatkan fitur login untuk mengakses. Perlu dilakukan setting terlebih dahulu pada database server [12] sehingga pencatatan cuti karyawan dapat dilakukan. Perlu identifikasi 
secara spesifik pada saat login agar memastikan pengguna yang sedang menggunakannya adalah karyawan yang mengajukan cuti.

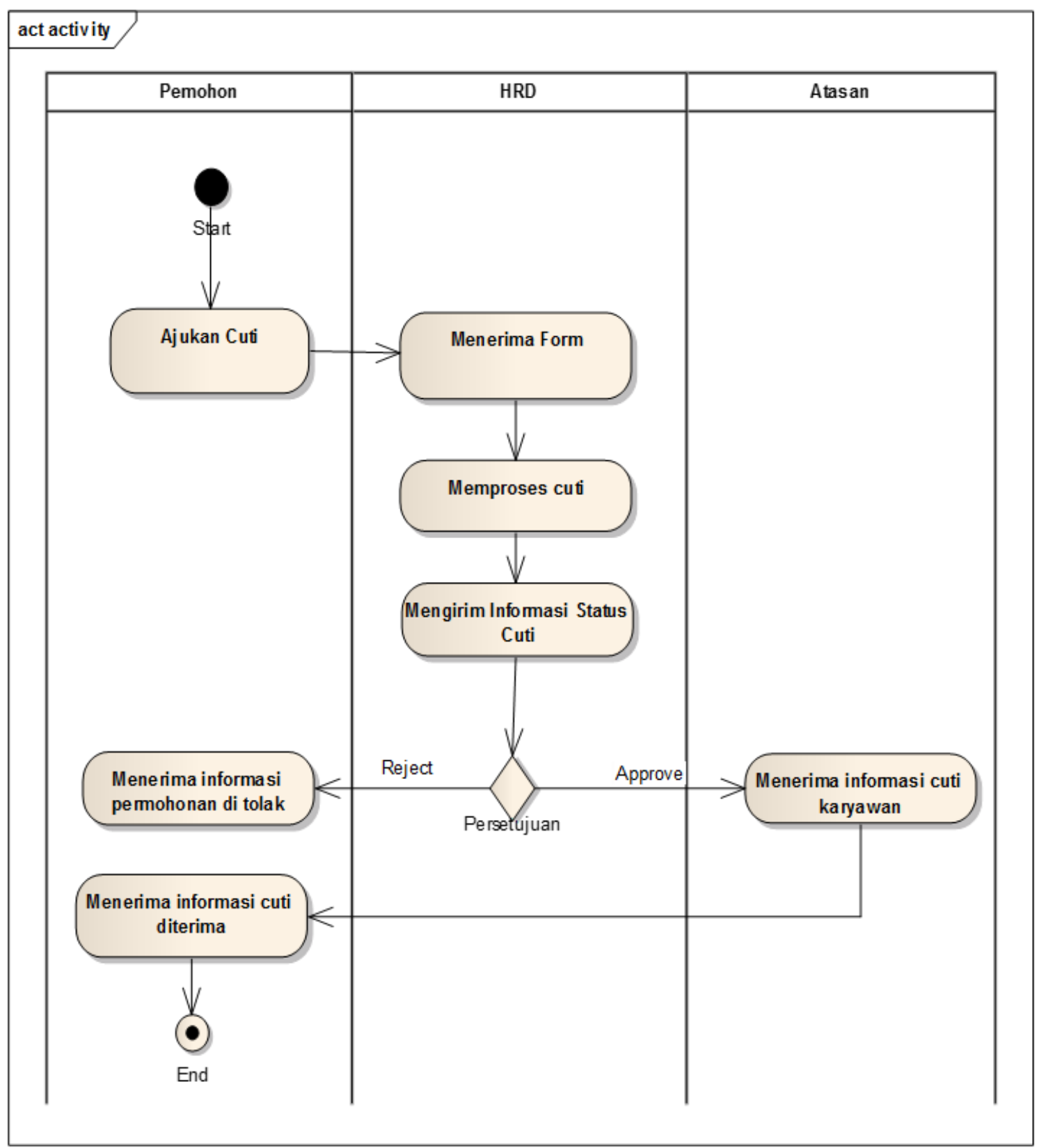

Gambar 2. Activity Diagram Sistem Manual Pengajuan Cuti 
Tabel 1. User Stories

\begin{tabular}{|c|c|c|c|c|}
\hline No & Masalah & \multicolumn{2}{|c|}{ Kebutuhan } & Prioritas \\
\hline 1 & $\begin{array}{l}\text { Karyawan tidak } \\
\text { bisa mengajukan } \\
\text { cuti secara } \\
\text { mandiri }\end{array}$ & $\begin{array}{l}\text { 1. Fungsi } \\
\text { sesuai } \\
\text { Karyawan } \\
\text { 2. Fungsi } \\
\text { Pengajuan }\end{array}$ & $\begin{array}{l}\text { Login } \\
\text { ID } \\
\text { Cuti }\end{array}$ & \\
\hline 2 & $\begin{array}{l}\text { Karyawan bekerja } \\
\text { secara mobile }\end{array}$ & $\begin{array}{l}\text { 3. Fungsi Pe } \\
\text { Cuti }\end{array}$ & laporan & Utama \\
\hline
\end{tabular}

Kriteria sistem ini dapat berjalan yaitu sistem mampu mencatat pengajuan cuti dari karyawan untuk kemudian diverifikasi oleh admin departemen sumber daya manusia. Semua data tersebut harus dapat disimpan dalam database melalui internet dan bersifat real-time sehingga dapat mengeluarkan laporan pengajuan cuti dari penggunanya.

\subsubsection{Aktifitas Desain}

Pada aktifitas desain, penulis menggunakan Class Responsibility Collaboration untuk mendesain aplikasi sistem absensi berbasis Android yang dijabarkan pada Tabel 2.

Tabel 2. Class Responsibility Collaboration Card

\begin{tabular}{|c|c|}
\hline class : Register & \\
\hline Responsibility & Collaboration \\
\hline $\begin{array}{l}\text { Nomor induk pegawai } \\
\text { (NIP) }\end{array}$ & \multirow[t]{2}{*}{ User } \\
\hline Username & \\
\hline Id Android & \\
\hline Password & Admin \\
\hline
\end{tabular}

\begin{tabular}{|l|l|}
\hline \multicolumn{2}{|l|}{ class : User } \\
\hline Responsibility & Collaboration \\
\hline $\begin{array}{l}\text { Nomor induk pegawa } \\
\text { (NIP) }\end{array}$ & \\
\hline Username & \\
\hline Latitude & \multirow{2}{*}{ GPS Tracking } \\
\hline Longitude &
\end{tabular}

\begin{tabular}{|l|l|}
\hline \multicolumn{2}{|l|}{ class : Admin } \\
\hline Responsiibility & Collaboration \\
\hline Id Admin & \\
\hline Username & \\
\hline Password & \\
\hline
\end{tabular}

\begin{tabular}{|l|l|}
\hline \multicolumn{2}{|l|}{ class : GPSTracking } \\
\hline Responsibility & Collaboration \\
\hline Latitude & \\
\hline Longitude & \\
\hline
\end{tabular}

\begin{tabular}{|c|c|}
\hline class : Absensi & \\
\hline Responsibility & Collaboration \\
\hline $\begin{array}{l}\text { Nomor induk pegawai } \\
\text { (NIP) }\end{array}$ & User \\
\hline Id Android & Register \\
\hline Latitude & \multirow{2}{*}{ GPS Tracking } \\
\hline Longitude & \\
\hline \multicolumn{2}{|l|}{ Waktu Masuk } \\
\hline MAC Address Masuk & \multirow{2}{*}{ MAC Address Track } \\
\hline Lokasi Masuk & \\
\hline Tanggal & \\
\hline Latitude Keluar & \multirow{2}{*}{ GPS Tracking } \\
\hline Longitude Keluar & \\
\hline Waktu Keluar & \\
\hline MAC Address Keluar & \multirow{2}{*}{ MAC Address Track } \\
\hline Lokasi Keluar & \\
\hline Tanggal Keluar & \\
\hline Keterangan & \\
\hline
\end{tabular}

\begin{tabular}{|l|l|}
\hline \multicolumn{2}{|l|}{ class : MACAddressTrack } \\
\hline Responsibility & Collaboration \\
\hline MACAddress & \\
\hline Lokasi & \\
\hline
\end{tabular}

\begin{tabular}{|l|l|}
\hline \multicolumn{2}{|l|}{ class : Cuti } \\
\hline Responsibility & Collaboration \\
\hline $\begin{array}{l}\text { Nomor induk pegawai } \\
\text { (NIP) }\end{array}$ & Use \\
\hline Id Android & \\
\hline Latitude & GPS Tracking \\
\hline Longitude & \\
\hline Waktu Pengajuan & \\
\hline Waktu Awal Cuti & \\
\hline Waktu Akhir Cuti & \\
\hline Jenis Cuti & \\
\hline
\end{tabular}




\subsubsection{Aktifitas Pengkodean}

Pada tahap pengkodean, penulis menggunakan bahasa JAVA untuk sistem absensi di sistem operasi Android 5.x dan PHP serta MySQL untuk administrasi dan pencatatan database di hosting.

4.2.4 Aktifitas Pengujian pada Telepon pintar bersistem operasi Android 5.x

\section{(Q) $\mathbb{Q} \Psi$ \\ Sistem Absensi \\ SISIEM INFORMASI \\ ABSENST}

\section{ㄱ.}
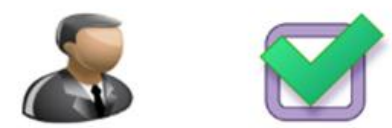

Registrasi

Check-In

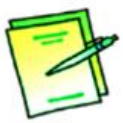

Ijin

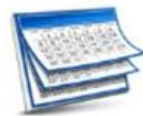

Cuti

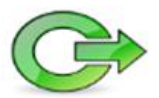

Check Out

Gambar 3. Tampilan Menu Utama

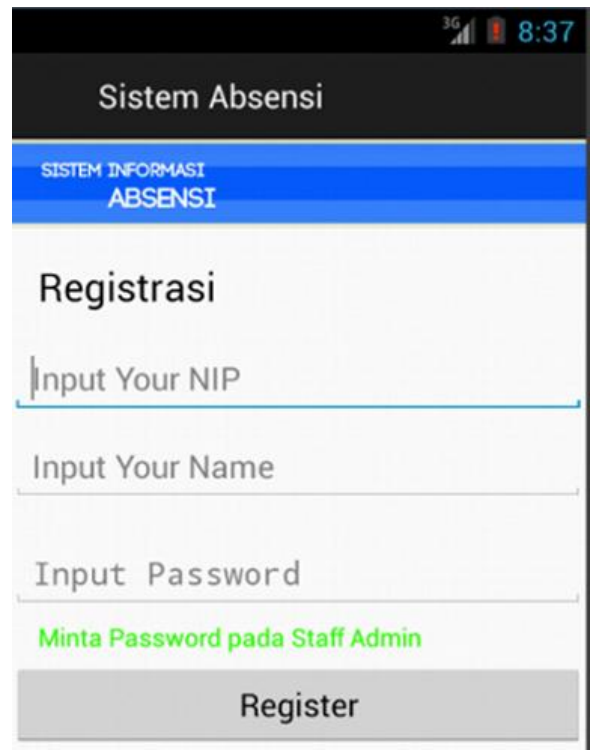

Gambar 4. Pengujian Registrasi 
Dalam membuat sistem pengajuan cuti berbasis Android ini dan menguji coba fungsinya, diperlukan seorang karyawan melakukan kegiatan pengajuan cuti ini di suatu tempat. Fitur pencatatan GPS pada fungsi pengajuan cuti ini bisa dipakai dan bisa juga dimatikan, tujuannya hanya sebagai informasi tambahan kapan dan dimana si karyawan mengajukan cuti, apalagi jika karyawan tersebut sedang dinas di kantor pelanggan ketika ingin mengajukan cuti. Pada tahap pengujian aplikasi, file installasi apk dikirim ke telepon pintar Android 5.x untuk kemudian di-install pada telepon pintar tersebut. Jalankan Sistem Absensi untuk masuk ke menu utama (Gambar 3).

Langkah pertama untuk menjalankannya yaitu melakukan pendaftaran (registrasi) telepon pintar dan ID pengguna jika pengguna belum pernah melakukan pendaftaran sebelumnya dengan telepon pintar tersebut (Gambar 4).

Jika sudah terdaftar, maka admin akan memasukan data lengkap sesuai ID yang didaftarkan untuk menetapkan area dimana ID tersebut akan melakukan absensi (Tabel 3 dan Gambar 5).

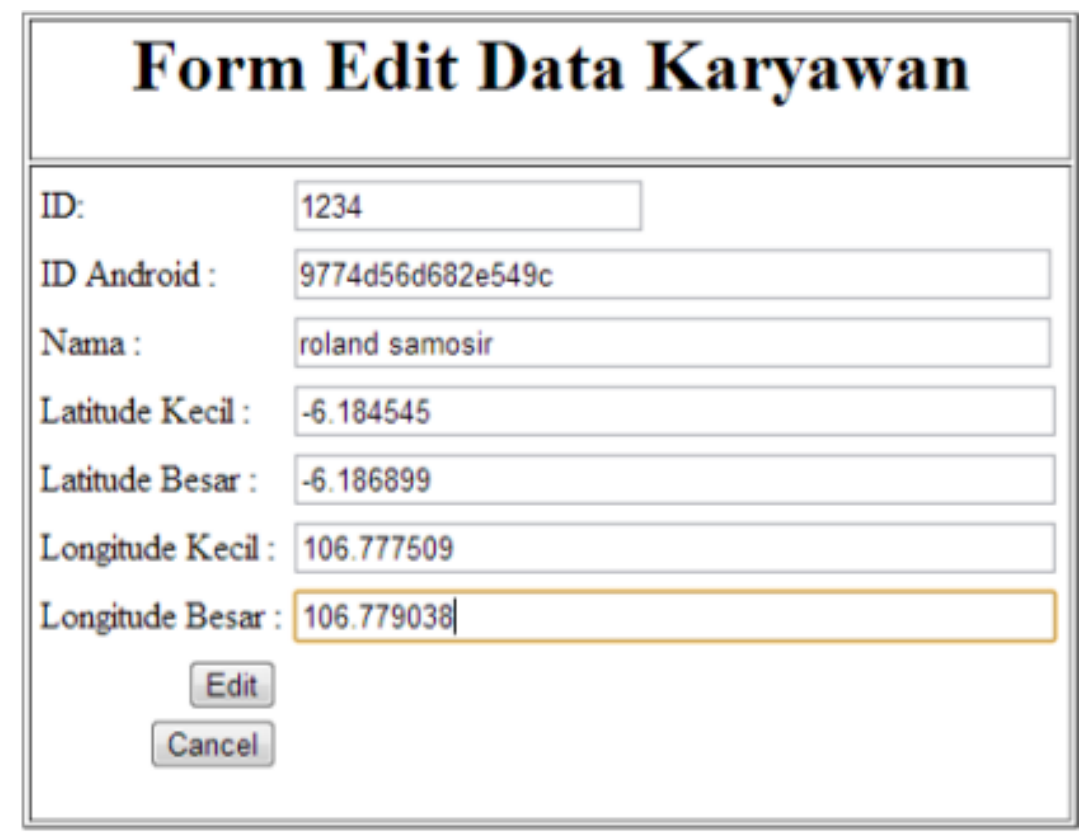

Gambar 5. Tampilan Halaman Edit Karyawan

Tabel 3. Daftar Karyawan

DATA KARYAWAN

\begin{tabular}{|c|c|c|c|c|c|c|c|}
\hline ID & ID Android & Nama & Latitude Kecil & Latitude Besar & Longitude Kecil & Longitude Besar & \\
\hline 1234 & $9774 d 56 d 682 \mathrm{e} 549 \mathrm{c}$ & karyawan 1 & -6.184737 & -6.186763 & 106.777608 & 106.778246 & delete edit \\
\hline 1235 & $2041 q 43 t 135 n 482 v$ & karyawan 2 & -6.184737 & -6.186763 & 106.777608 & 106.778246 & delete edit \\
\hline 1236 & $9238 \times 14 \mathrm{f} 423 \mathrm{j} 937 \mathrm{~d}$ & karyawan 3 & -6.184737 & -6.186763 & 106.777608 & 106.778246 & delete edit \\
\hline 1237 & $1068 \mathrm{~g} 67 \mathrm{k} 598 \mathrm{a} 620 \mathrm{p}$ & karyawan 4 & -6.184737 & -6.186763 & 106.777608 & 106.778246 & delete edit \\
\hline 1238 & $4976 \mathrm{r} 921150 \mathrm{p} 469 \mathrm{z}$ & karyawan 5 & -6.184737 & -6.186763 & 106.777608 & 106.778246 & delete edit \\
\hline
\end{tabular}

Setalah informasi lengkapnya dipenuhi, penggunakan melakukan proses Check In dan Check Out melalui telepon pintar-nya dengan menyalakan fungsi GPS dan koneksi pada WiFi Hotspot di daerah tersebut dahulu (Gambar 6). 


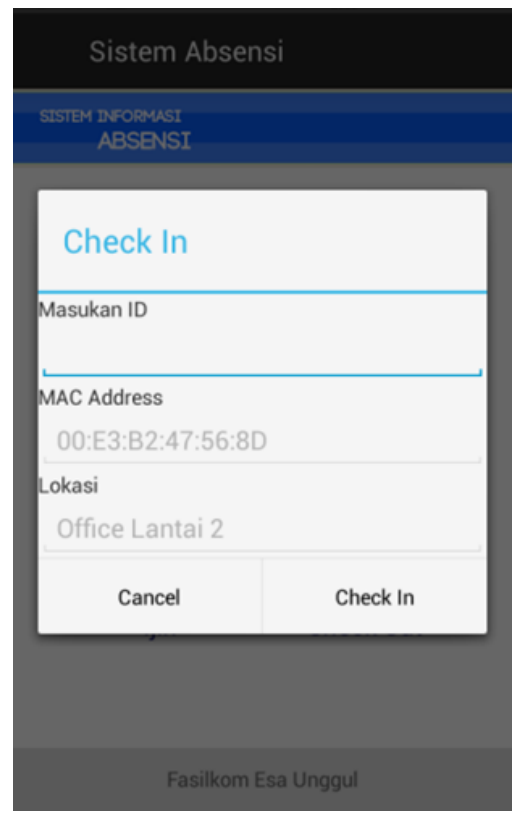

Gambar 6. Pengujian Check-in

Untuk pengajuan cuti maka karyawan masuk kedalam menu pengajuan cuti untuk memasukan tanggal mulai cuti dan tanggal berakhir cuti (Gambar 7), contoh pada gambar karyawan dengan kode A100 mengajukan cuti dari tanggal 31 Mei 2016 sampai dengan tanggal 6 Juni 2016. Lalu karyawan juga diminta untuk memasukan jenis cuti yang ingin diambil (Gambar 8). Dari data yang dimasukkan tersebut, sistem melakukan perhitungan bahwa ada 5 hari cuti yang diambil karyawan tersebut, selanjutnya akan dicek di sistem sisa cuti karyawan, jika masih mencukupi maka sistem akan memotong jatah cuti karyawan tersebut, jika tidak maka akan memberikan notifikasi bahwa sisa cuti tidak mencukupi sehingga otomatis sisa tidak masuk karyawan statusnya menjadi izin atau alpa.

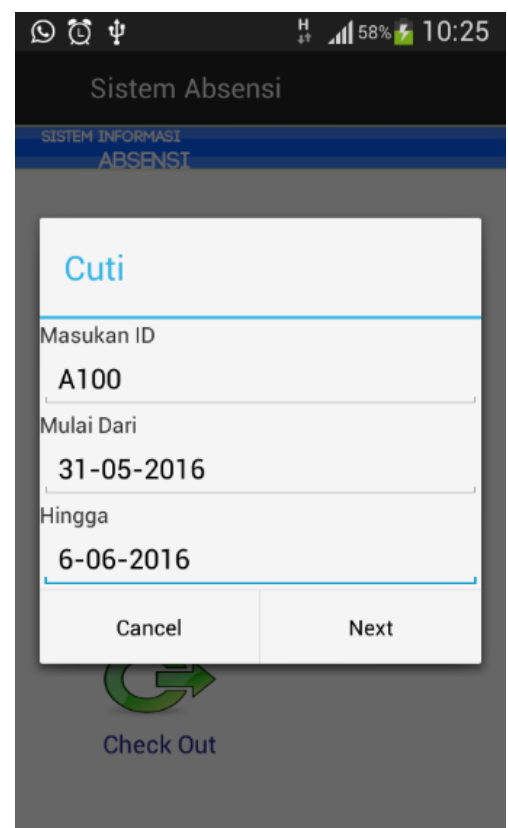

Gambar 7. Pengujian Masuk Tanggal Cuti 


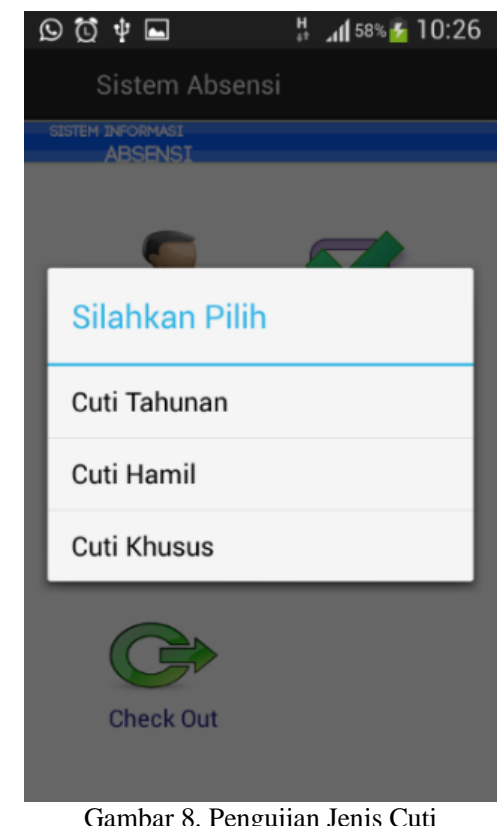

\section{Kesimpulan dan Saran}

Setelah melakukan proses penelitian dalam merancang dan membangun sistem absensi dengan fungsi pengajuan cuti pada Android versi 4.x maka dapat disimpulkan beberapa hal sebagai berikut:

1) Telepon pintar berbasis sistem operasi Android dapat digunakan untuk fungsi pengajuan cuti yang diintegrasikan dengan sistem absensi yang pernah dibuat sebelumnya.

2) Dengan terintegrasinya sistem absensi dan sistem pengajuan cuti, laporan kehadiran karyawan semakin lengkap karena terlihat jelas jika sedang tidak masuk apakah izin, sakit, alpa atau sedang cuti, selain itu jatah cuti karyawan dapat semakin tekontrol serta terkelola dengan baik walaupun karyawan tersebut bekerja secara outsourcing di perusahaan lain.

Sistem absensi dan pengajuan cuti ini bisa ditambahkan fungsi-fungsi lainnya yang berhubungan dengan pengelolaan sumber daya manusia. Selain mengajukan ijin juga bisa ditambahkan pengajuan dan pelaporan perjalanan dinas dengan mengupload bukti-bukti terkait melalui fasilitas camera yang dimiliki smartphone.

Perlu dikembangkan pula fasilitas login sistem yang lebih kredibel contohnya dengan menambahkan fasilitas pemindai data biometrik dari penggunanya. Dengan adanya fasilitas login yang baik, maka pemakaian dan tujuan absensi menggunakan perangkat mobile ini semakin maksimal terutama di sisi keamanan dan keakuratan data/penggunanya. Selain itu data dari sistem absensi dan cuti ini bisa diintegrasikan dengan sistem penggajian karena memberikan data ringkasan mengenai kehadiran karyawan walaupun karyawan tersebut bekerja secara bergerak.

Selain itu sistem ini juga masih bisa dikembangkan pada sistem operasi perangkat telepon pintar lainnya seperti iOS, Blackberry dan Windows Phone. Deangan demikian perangkat yang digunakan tidak terbatas pada sistem operasi Android. 


\section{Daftar Rujukan}

[1] F. Adikara, "Analisis dan Perancangan Sistem Absensi Berbasis Global Positioning Sistem (GPS) pada Android ver. 4.x," in Prosiding SNTI, Jakarta, 2013.

[2] F. Adikara, "Pemanfaatan MAC Address Hotspot dalam Pengembangan Sistem Absensi GPS Dalam Rangka Meningkatkan Kekuaratan Posisi Pengguna," Jurnal Sisfo, vol. 5, no. 4, 2015.

[3] B. Ronald and . K. Gerwin, "The Conditional Benefits of Early User Involvement at Employee Self-Service Applications in Four Dutch Ministries," The Netherlands : International Journal of Business Information System, vol. 5, no. 2, 2010.

[4] Marimin, Sistem Informasi Manajemen Sumber Daya Manusia, Jakarta: Grasindo, 2006.

[5] D. Pendidikan Nasional, Kamus Besar Bahasa Indonesia Pusat Bahasa Edisi Keempat, Jakarta: PT. Gramedia Pustaka Utama, 2008.

[6] N. S. H., Pemrograman Aplikasi Mobile Telepon pintar Dan Tablet PC Berbasis Android, Bandung: Informatika, 2012.

[7] R. Meier, Professional Android 4 Application Development, London: Wrox, 2012.

[8] P. R. Indonesia, UNDANG-UNDANG REPUBLIK INDONESIA NO.13 TAHUN 2003, Jakarta: Republik Indonesia, 2003.

[9] R. S. Pressman, Software Engineering A practitioner's Approach 8th Edition, New York: Mc-Graw Hill, 2014.

[10] J. Rubin and D. Chisnell, , andbook of Usability Testing How to Plan, Design, and Conduct Effective Tests, Indianapolis: Wiley Publishing, 2008.

[11] G. Millete and A. Stroud, Professional Sensor Android Programming, Indianapolis: John Wiley \& Sons, 2012.

[12] R. Elmasri and S. B. Navathe, Database Sistems Models, Languages, Design and Application Programming Sixth Edition, Massachusetts: Pearson Education Inc, 2011. 